\title{
THE EFFECT OF METHANOL-DIESEL BLENDED RATIO ON CI ENGINE PERFORMANCE
}

\author{
T. Yusaf*1, I. Hamawand ${ }^{1}$, P. Baker ${ }^{1}$ and G. Najafi ${ }^{2}$ \\ 1- National Centre for Engineering in Agriculture (NCEA), Faculty of Engineering and \\ Surveying, University of Southern Queensland, Toowoomba 4350 QLD, Australia \\ 2- Tarbiat Modares University, Tehran, Iran \\ *Email: yusaft@usq.edu.au
}

\begin{abstract}
In the current work, a comprehensive study on the possibility of using methanol as an alternative fuel for diesel engines was carried out. Methanol was mixed at different ratios with diesel fuel. The mixing ratios of methanol to diesel were 0:100, 10:90, 20:80 and 30:70. The effects of methanol fraction on engine power, torque, brake specific fuel consumption (BSFC), brake thermal efficiency and exhaust temperature were experimentally investigated at variant engine speeds. The engine used to carry out these experiments is a four-stroke four-cylinder diesel engine. The results showed that mixing methanol at different fractions with diesel fuel has a significant effect on the engine performance. The methanol to diesel ratio of 10:90 exhibited the lowest exhaust temperature and achieved an improvement in the output power of approximately $70 \%$ compared to the other ratios. Also, the brake thermal efficiency improved at all the mixing ratios used. Furthermore, the BSFC of pure diesel fuel registered a lower value than any other mixing ratio. It has been shown in this research that the addition of $10 \%$ methanol to the diesel fuel may have a great impact on the engine performance and the environment
\end{abstract}

Keywords: Methanol; diesel engine; engine performance; methanol-diesel blends.

\section{INTRODUCTION}

Nowadays, many researchers are promoting the use of methanol as an alternative fuel for internal combustion engines due to its ability to produce power with less emission. Methanol $\left(\mathrm{CH}_{3} \mathrm{OH}\right)$ is an alcohol that was originally produced by the destructive distillation of wood. In recent decades, methanol has been produced in large quantities from natural gas using reformation gas process. This process involves passing carbon monoxide and hydrogen gases over a suitable catalyst under appropriate conditions of pressure and temperature (Warring, 1993). Methanol is usually introduced into the engine through the engine air intake (fumigation) (Adelman et al., 1972; Havemann et al., 1954; Klaus \& Pederson, 1977). The addition of a high oxygen content and high volatility component such as methanol to diesel or biodiesel can be a promising technique in diesel engines (Sundar Raj, \& Sendilvelan, 2010; Azad, Ameer Uddin, \& Alam, 2012). It can be used efficiently without any modifications in the engine (Qi et al., 2010; Rahim, Mamat, Taib, \& Abdullah, 2012). Klaus and Pederson (1977) claimed that the brake thermal efficiency can be improved by about $30 \%$ when methanol is used. However, it has also been observed when the engines were operated using methanol alone, that they were prone to pre-ignition (Yuksel \& Yuksel, 2004). In a study by Sayin, Ozsezen, and Canakci (2010), the brake specific fuel consumption (BSFC) was 
found to be improved under high-load operating conditions. However, total unburned hydrocarbon THC and CO emissions for dual-fuel operation increased when methanol was added. In another study by Sayin et al. (2009), it was found that increasing the methanol ratio in the fuel blend caused an increase in the BSFC and decrease in BTE by about $38 \%$ and $42 \%$, respectively. This was related to the lower heating value (LHV) of the methanol fuel, which is lower than that of the diesel fuel. It has been reported worldwide that alcohols such as methanol and ethanol have the potential to become an alternative fuel for IC engines (Yuksel \& Yuksel, 2004; (Mat Yasin, Mamat, Sharma, \& Yusop, 2012). Pure methanol cannot be used directly in unmodified diesel engines because it will require spark or ignition assistance or a fuel additive. However, use of diesel blended with up to $20 \%$ of methanol by volume requires only minor engine modifications (Lin \& Chao, 2002). It has been reported that using blended fuel will always result in better performance than conventional fuel (Liu et al., 2007). Table 1 summarizes some of the chemical and physical properties of engine fuels that are commonly in use (Lu \& Liu, 2006; Liu \& Li, 2006; Liao et al., 2005). From Table 1, the exhaust gas components produced from methanol engines are found to be generally low and less toxic than other fuels. Methanol-fueled trucks and buses emit almost no particulate matter (which causes smoke, and can also be carcinogenic), and much less nitrogen oxide (NOx) than using diesel-fueled alone. Methanol extracts much more heat as it vaporizes because it has a higher latent heat of vaporization than diesel. This can lead to a cooling effect on the cylinder charge and lower NOx emissions (Bayraktar, 2008). Also, methanol is less flammable than gasoline. Methanol has a higher laminar flame propagation speed, which may contribute to the combustion process being completed earlier, which in turn leads to improved combustion efficiency. Also, the fuel blends have a longer ignition delay time than diesel fuel. The ignition delay period increases with increasing methanol (Özaktas et al., 2000). Furthermore, methanol is a high-octane fuel that offers excellent acceleration and vehicle power. Though the latent heat of methanol is high, this may increase the engine volumetric efficiency and thus increase engine power. Economically, methanol can be produced, distributed, and sold to consumers at prices that are competitive with gasoline and diesel (Warring, 1993; Yusaf, 2009; Ghobadian et al., 2009; Ghobadian, Najafi, \& Nayebi, 2013; Yao et al., 2008).

Table 1. Comparison of fuel properties

\begin{tabular}{lcccc}
\hline \multicolumn{1}{c}{ Property } & Iethanol & ithanol & Jasoline & Diesel \\
\hline Chemical formula & $\mathrm{CH}_{3} \mathrm{OH}$ & $\mathrm{C}_{2} \mathrm{H}_{5} \mathrm{OH}$ & $\mathrm{C}-\mathrm{C}$ mix & $\mathrm{C}-\mathrm{C}$ mix \\
Molecular weight & 32 & 46 & - & - \\
Boiling point $\left({ }^{\circ} \mathrm{C}\right)$ & 64.5 & 78 & $40-190$ & $170-340$ \\
Density at $20^{\circ} \mathrm{C}(\mathrm{kg} / \mathrm{l})$ & 0.792 & 0.789 & 0.74 & 0.84 \\
Stoic. air/fuel ratio & $6.4: 1$ & $9: 1$ & $14.7: 1$ & - \\
Cetane no & 3 & 8 & 10 & $50-55$ \\
Octane no & 92 & 90 & $80-90$ & - \\
Calorific value $(\mathrm{kJ} / \mathrm{kg})$ & 23800 & - & 43600 & 44500 \\
Flash point $\left({ }^{\circ} \mathrm{C}\right)$ & 11 & - & -43 & 52 \\
Auto ignition temp $\left({ }^{\circ} \mathrm{C}\right)$ & 464 & 360 & $220-260$ & $180-240$ \\
\hline
\end{tabular}

From the above, it can be seen that there is a need and motivation to study the potential of using methanol diesel blend in compression ignition (CI) engines. The 
current work aims to investigate the possibilities of improving diesel engine performance by introducing methanol-diesel blend fuel to the engine. The effective parameters of a commercial CI engine at different blend ratios of methanol and diesel fuel were studied.

\section{EXPERIMENTAL STUDY}

\section{Engine Used}

In this study, a four-stroke four-cylinder diesel engine was selected for carrying out the experiments. Figure 1 is a schematic diagram of the engine which is coupled to a 130 $\mathrm{kW}$ eddy current dynamometer. Methanol is introduced through fuel injectors into the intake of each cylinder to form a homogeneous methanol/air mixture (Yao et al., 2008). The full details of the engine specifications are illustrated in Table2.

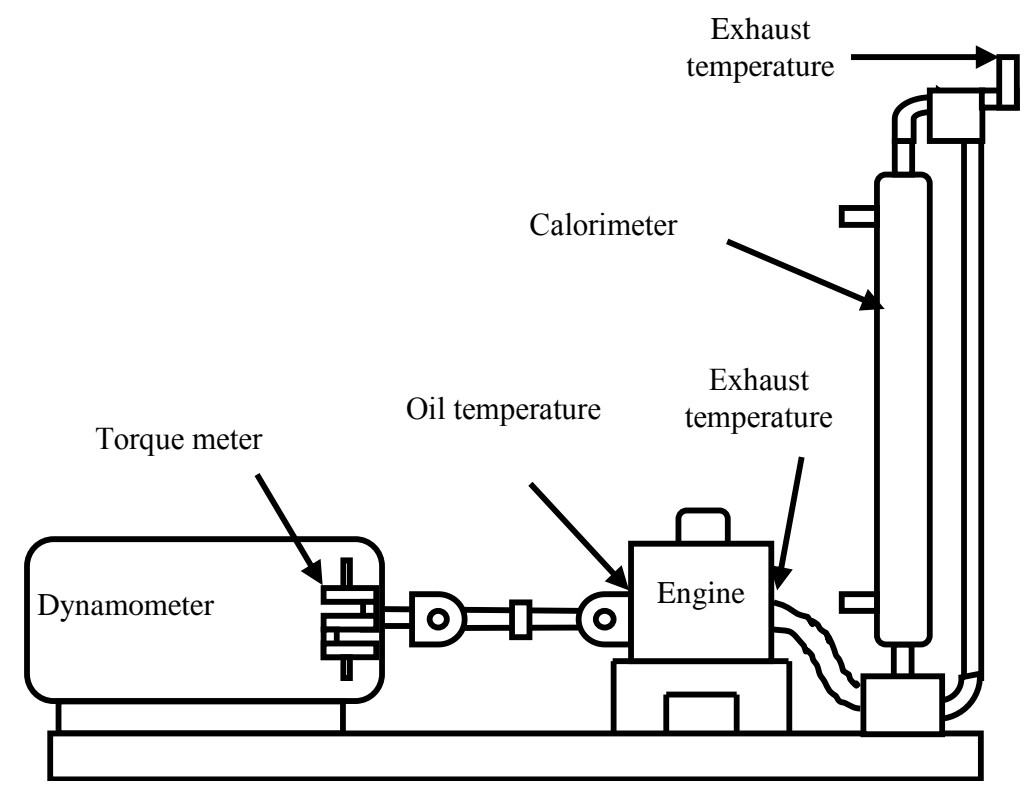

Figure 1. A sketch of the experimental rig

Table 2. Engine specifications

\begin{tabular}{lc}
\hline Model & Klockner- Humboldt- Deutz AG \\
\hline Type & F4L 913, four-stroke diesel Klockner- \\
No. of cylinders & Humboldt- Deutz AG 1 \\
Bore x stroke (mm) & 4 \\
Displacement (l) & 402 X 125 \\
Rated speed , rpm (max) & 2.086 \\
Compression ratio & 2800 \\
Firing order & $15.5: 1$ \\
Operating fuel injection pressure (bar) & $1-3-4-2$ \\
Compression Pressure (bar) & 175 \\
\hline
\end{tabular}




\section{Fuel Preparations}

Several ratios of methanol (99.8\% purity) to diesel were introduced to the engine through the engine air intake, i.e. containing $10 \mathrm{vol} . \%, 20 \mathrm{vol} . \%$ and $30 \mathrm{vol} . \%$ of methanol as a ratio of the diesel inlet to the engine. The properties of methanol and diesel compared to other fuels were presented in Table 1 above. For the testing, the calorific value of diesel is assumed to be $45.0 \mathrm{MJ} / \mathrm{kg}$ and the calorific value for methanol is taken to be $23.8 \mathrm{MJ} / \mathrm{kg}$. The specific gravity for diesel and methanol is 0.84 and 0.79 respectively. Calculated values for the lower calorific value (LCV) are presented in Table 3.

Table 3. Calculated lower calorific values (LCV).

\begin{tabular}{ccccccc}
\hline $\begin{array}{c}\text { Methanol } \\
\mathrm{b}\end{array}$ & $\begin{array}{c}\mathrm{CO}_{2} \\
\mathrm{~d}\end{array}$ & $\begin{array}{c}\mathrm{H}_{2} \mathrm{O} \\
\mathrm{e}\end{array}$ & $\begin{array}{c}\mathrm{O}_{2} \\
\mathrm{c}\end{array}$ & $\begin{array}{c}\mathrm{Hf} \\
(\mathrm{kJ} / \mathrm{kMol})\end{array}$ & $\begin{array}{c}\text { Molecular } \\
\text { Weight }\end{array}$ & $\begin{array}{c}\mathrm{LCV} \\
(\mathrm{MJ} / \mathrm{kg})\end{array}$ \\
\hline 0 & 16 & 17 & 16 & -9957260 & 226 & -44.06 \\
0.1 & 14.5 & 15.5 & 14.45 & -9073131 & 206.6 & -43.92 \\
0.2 & 13 & 14 & 12.9 & -8189002 & 187.2 & -43.74 \\
0.3 & 11.5 & 12.5 & 11.35 & -7304873 & 167.8 & -43.53 \\
0.4 & 10 & 11 & 9.8 & -6420744 & 148.4 & -43.27 \\
0.5 & 8.5 & 9.5 & 8.25 & -5536615 & 129 & -42.92 \\
0.6 & 7 & 8 & 6.7 & -4652486 & 109.6 & -42.45 \\
0.7 & 5.5 & 6.5 & 5.15 & -3768357 & 90.2 & -41.78 \\
0.8 & 4 & 5 & 3.6 & -2884228 & 70.8 & -40.74 \\
0.9 & 2.5 & 3.5 & 2.05 & -2000099 & 51.4 & -38.91 \\
\hline
\end{tabular}

\section{RESULTS AND DISCUSSION}

First of all, the fuel track of the engine was set to operate on maximum operating conditions, with the maximum fuel injection position set for full load conditions. Next, the engine was operated on maximum speed, then the speed was gradually reduced by increasing its load. The effects of the blending ratio of the methanol-diesel mixture on torque, input power, output power, brake specific fuel consumption, brake thermal efficiency, and exhaust gas temperature were measured and the results are presented in the following sections.

\section{Torque}

Figure 2 shows the torque behavior against engine speed at different blended ratios of methanol-diesel fuels. In general, the torque decreases when the engine speed increases. However, there are remarkable differences in the trends. For diesel, the curve is quite constant with a small gap between the maximum and minimum values. The starting torque is high at low engine speed and decreases at high engine speed. Meanwhile, mixing the diesel with methanol shows a slight increase in the torque at higher speeds. However, at all engine speeds, methanol-diesel blended fuels in all ratios exhibit higher torque than diesel fuel alone. This is more obvious when $10 \mathrm{vol} \%$ methanol is used. 


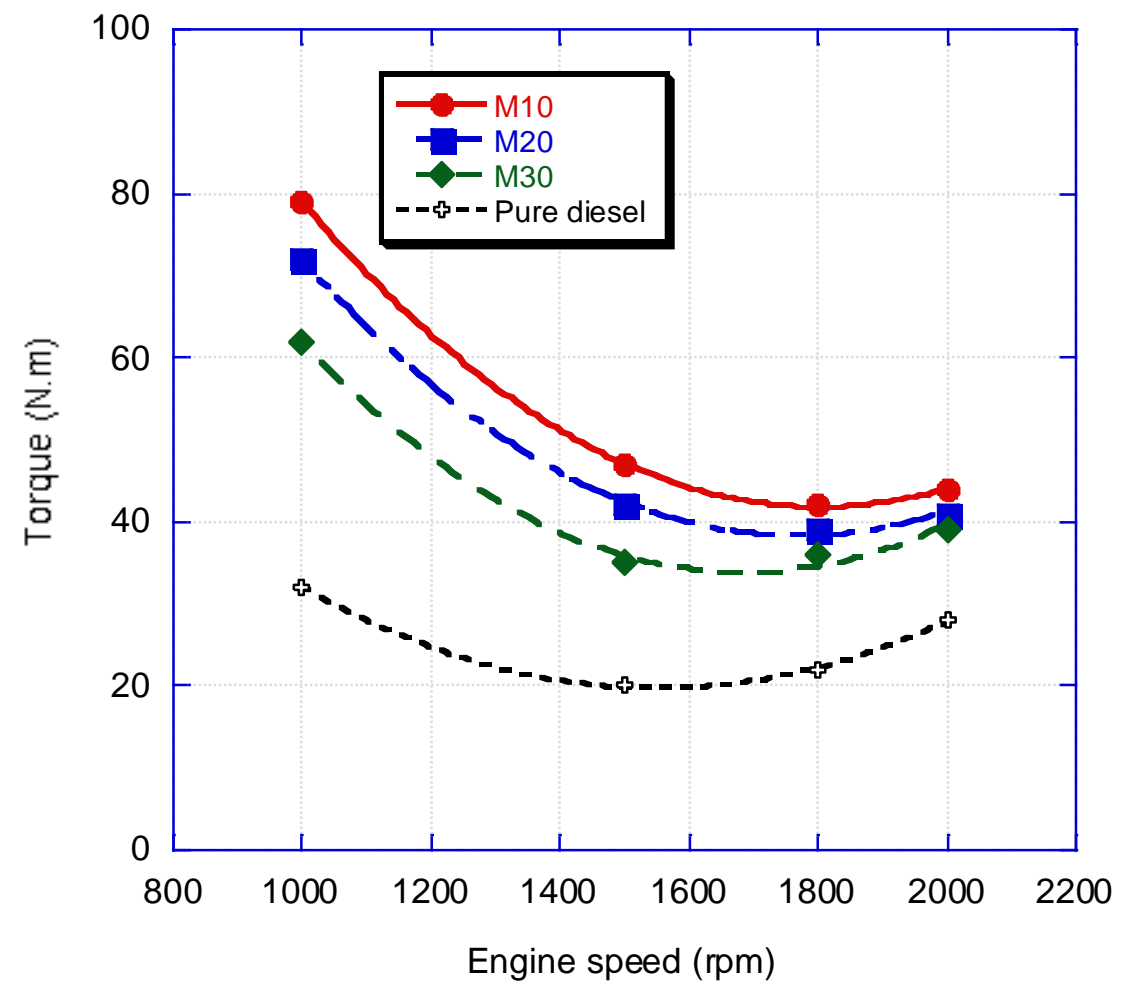

Figure 2. Engine torque vs. engine speed for different methanol-diesel blended fuels at full load.

\section{Input and Output Powers}

Input power to the engine can be estimated through the amount of fuel injected into it. Theoretically, it is determined based on the flow-rate and the lower calorific value of the blended/pure fuels. The lower calorific value of methanol is approximately half that of diesel, with values of $23.8 \mathrm{MJ} / \mathrm{kg}$ and $44.5 \mathrm{MJ} / \mathrm{kg}$ for methanol and diesel respectively. For the current experimental work, Figure 3 shows the effect of the various blended fuels on engine power. In general, it can be seen that the input power of the blended fuel gives higher power than the pure diesel. It is well known that engine power is highly controlled by the combustion efficiency. However, it has been reported by Ghobadian et al. (2009) that misfire may occur, and a small amount of unburned methanol and air will be trapped in the clearance volume at the end of the exhaust stroke. This will lead to a lean methanol-air mixture during the following compression stroke. Moreover, at the end of the compression stroke, prior to the next fuel injection, a small amount of vaporized methanol left at elevated temperatures may in turn enhance the combustion efficiency. The above could explain the better input performance of the blended fuel compared to the pure diesel. Regarding the output power, similar trends and findings to those for the input power can be observed in Figure 4. The improvement in the output power is about $70 \%$ when $10 \%$ methanol is blended with $90 \%$ diesel. 


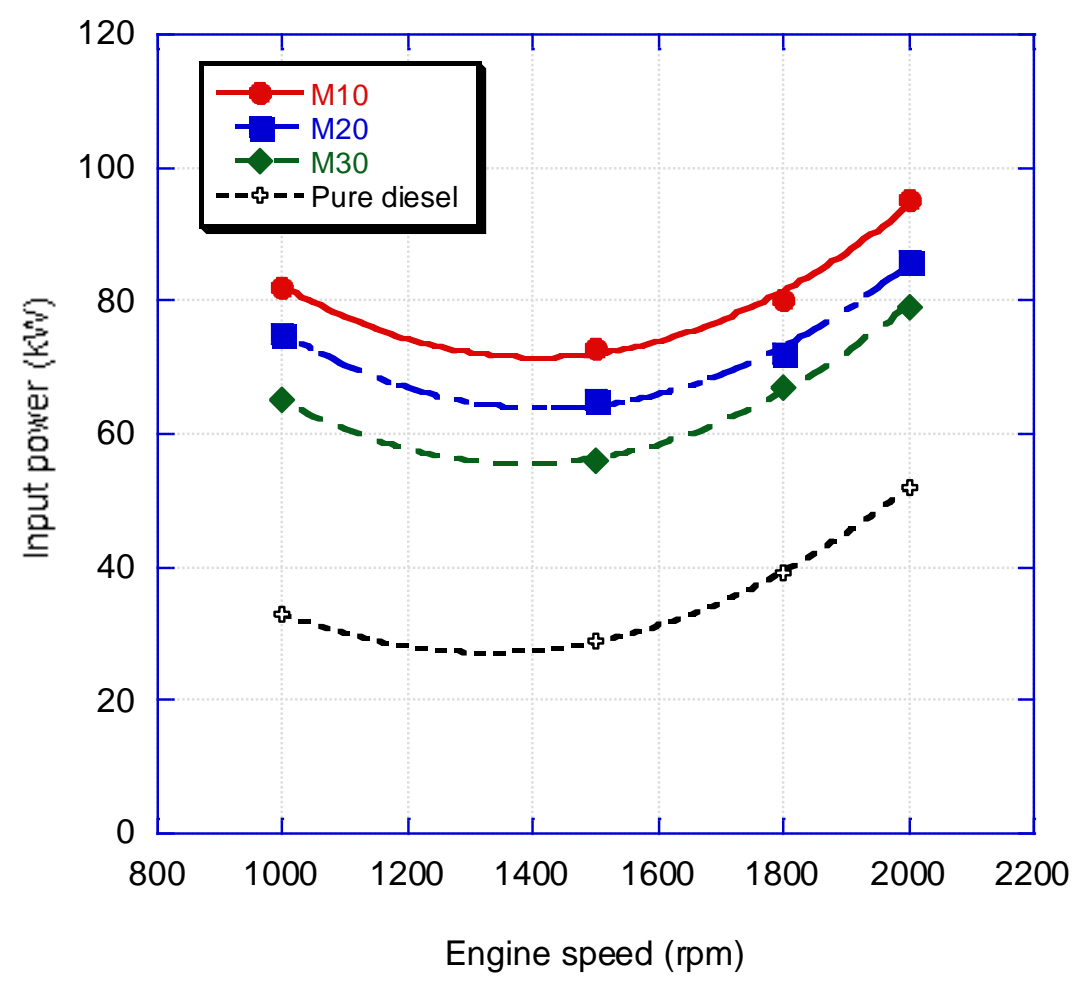

Figure 3. Input power vs. engine speed for different methanol-diesel blended fuels at full load.

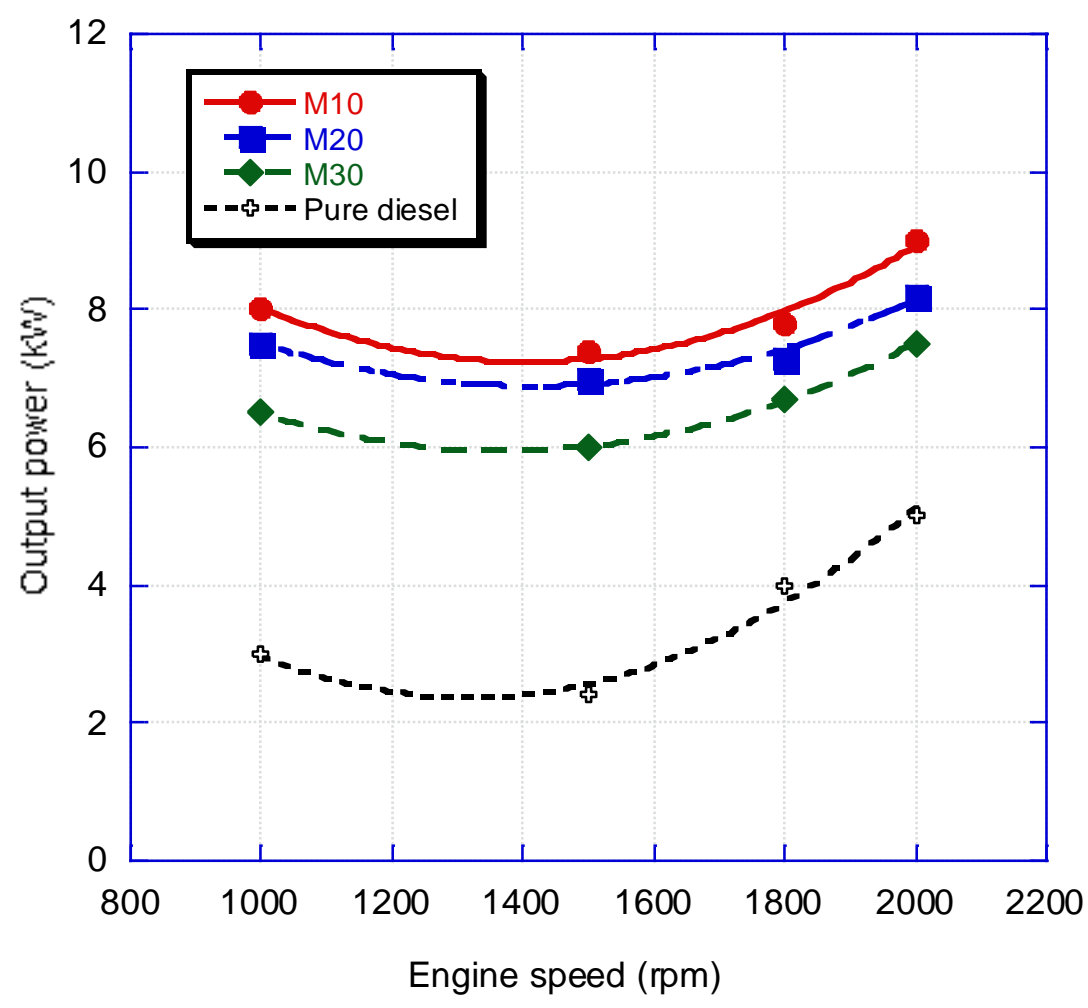

Figure 4. Output power vs. engine speed for different methanol-diesel blended fuels at full load. 


\section{Brake Specific Fuel Consumption}

The brake specific fuel consumption (BSFC), which is defined as the fuel flow-rate per hour $(\mathrm{kg} / \mathrm{h})$ divided by the engine's brake power $(\mathrm{kW})$, is a measure of the engine efficiency. The BSFC versus engine speed is presented in Figure 5, which represents the BSFC at maximum operating conditions. A significant difference between blended fuel and diesel fuel can be observed in the figure. The lowest BSFC is achieved with $30 \%$ methanol and $70 \%$ diesel blended fuel. This finding contradicts the finding of Sayin et al. (2010). Also, the specific consumption of diesel fuel is very low compared to any mixed ratio. This is due to the difference in the lower calorific values of both types of fuels. The lower calorific value for blended fuel is less than for diesel alone. In order to get the same amount of input power, the amount of blended fuel must be increased. It is possible to increase the performance of the blended fuel by adding some additives to it.

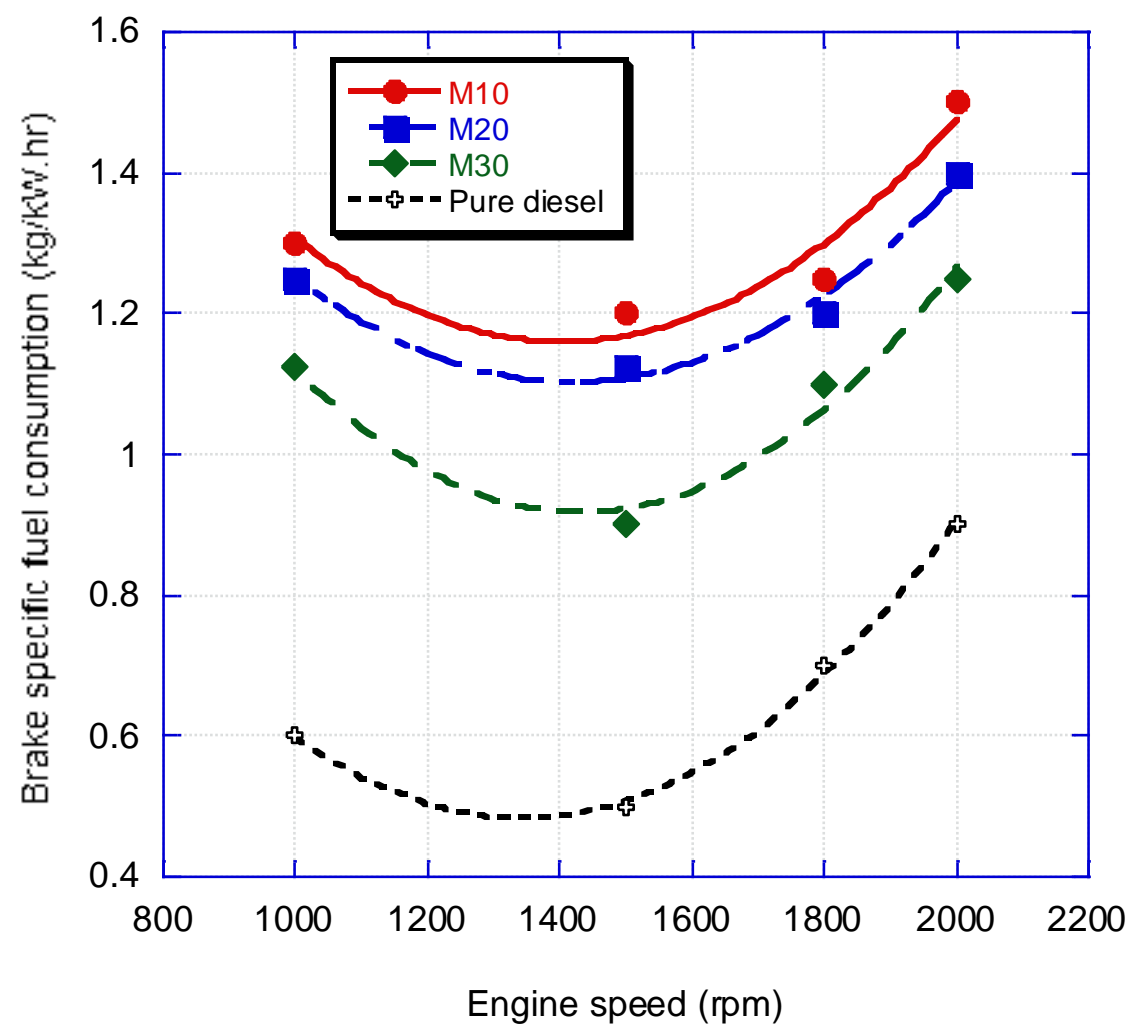

Figure 5. BSFC vs. engine speed for different methanol-diesel blended fuels at full load condition.

\section{Brake Thermal Efficiency}

Brake thermal efficiency is the percentage ratio of the brake output power and the input power. From the result presented in Figure 6, it is clear that using methanol in this test has led to a better brake thermal efficiency. This is due to the lean completed combustion when methanol is used. Fig. 6 shows the relationship between the brake thermal efficiency and engine speeds. It was found that using excessive methanol in the diesel engine is less beneficial at medium speeds around $1500 \mathrm{rpm}$. As shown in Fig. 6, the addition of $20 \%$ methanol produces higher efficiency than the $30 \%$ at $1500 \mathrm{rpm}$. 
However, at higher speeds M30 seems to produce higher efficiency than the pure diesel, M10 or M20.

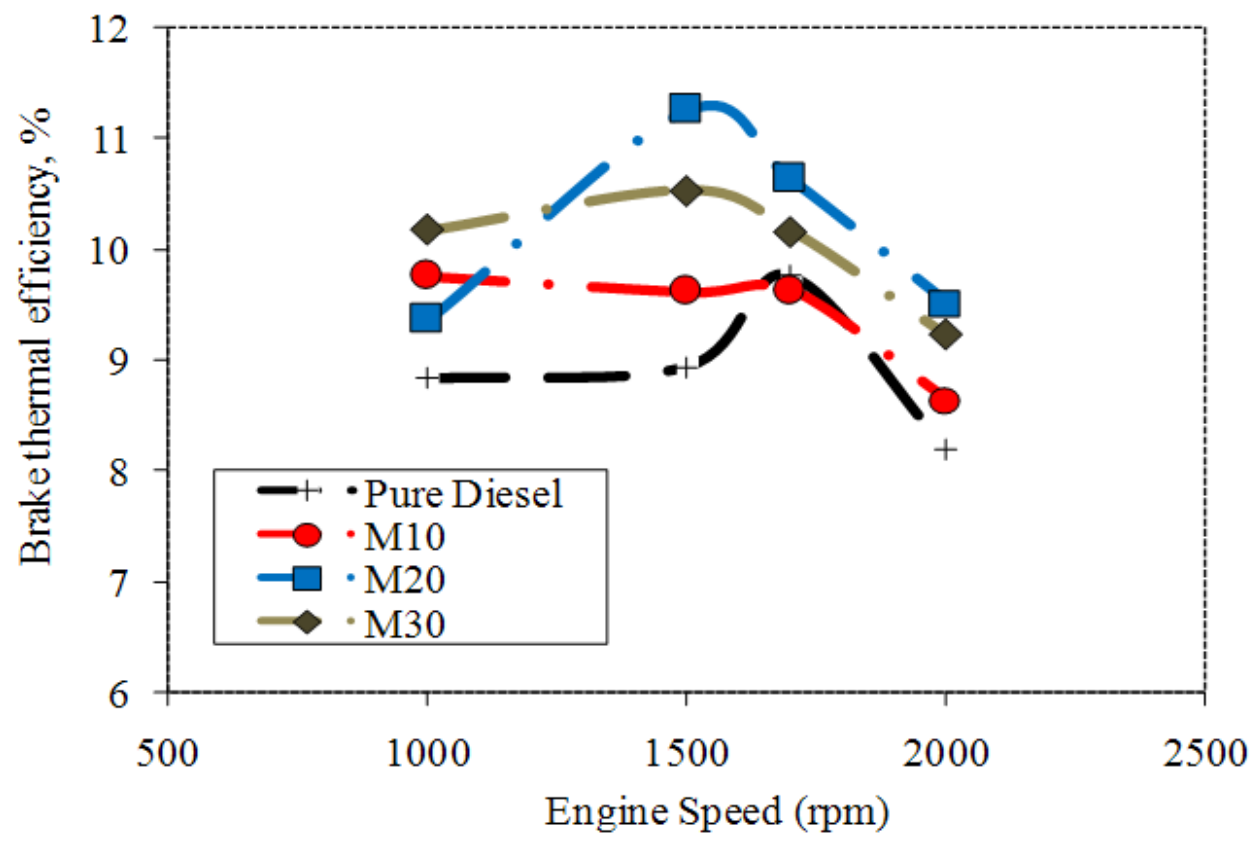

Figure 6. Brake thermal efficiency vs. engine speed.

\section{Exhaust Gas Temperature}

Figure 7 shows the exhaust temperature history against the engine speed at full load conditions. At all ranges of engine speed, the best blended ratio that produces the lowest exhaust temperature is $10 \%$ methanol and $90 \%$ diesel. The exhaust temperature of the engine using conventional fuel was found to be higher than any blended fuel ratio. High exhaust temperature coupled with lean combustion will lead to the formation of nitrogen oxide (NOx), which is poisonous and harmful to the environment. Consequently, using blended fuel is recommended to reduce the emission percentage of NOx. However, the combustion quality for both types of fuels is lean, the combustion of diesel alone is leaner than blended fuel, and therefore lean combustion produces more heat and thus increases the exhaust temperature. The lower exhaust temperature for blended fuel implies lower production of NOx. The oxygen content of the methanol helps to make the combustion leaner. The greater the amount of methanol fuel injected into the combustion chamber, the more oxygen will be available, and this will lead to complete combustion. The production of $\mathrm{NOx}$ is proportional to combustion efficiency. The better the combustion efficiency, the higher the value of the exhaust temperature, which increases the level of NOx production. Methanol-fueled vehicles normally show a lower content of $\mathrm{CO}$ and $\mathrm{CO}_{2}$ in their exhaust. However, attention needs to be paid to NOx content especially in vehicles that have high thermal efficiency (Yusaf, 2009). 


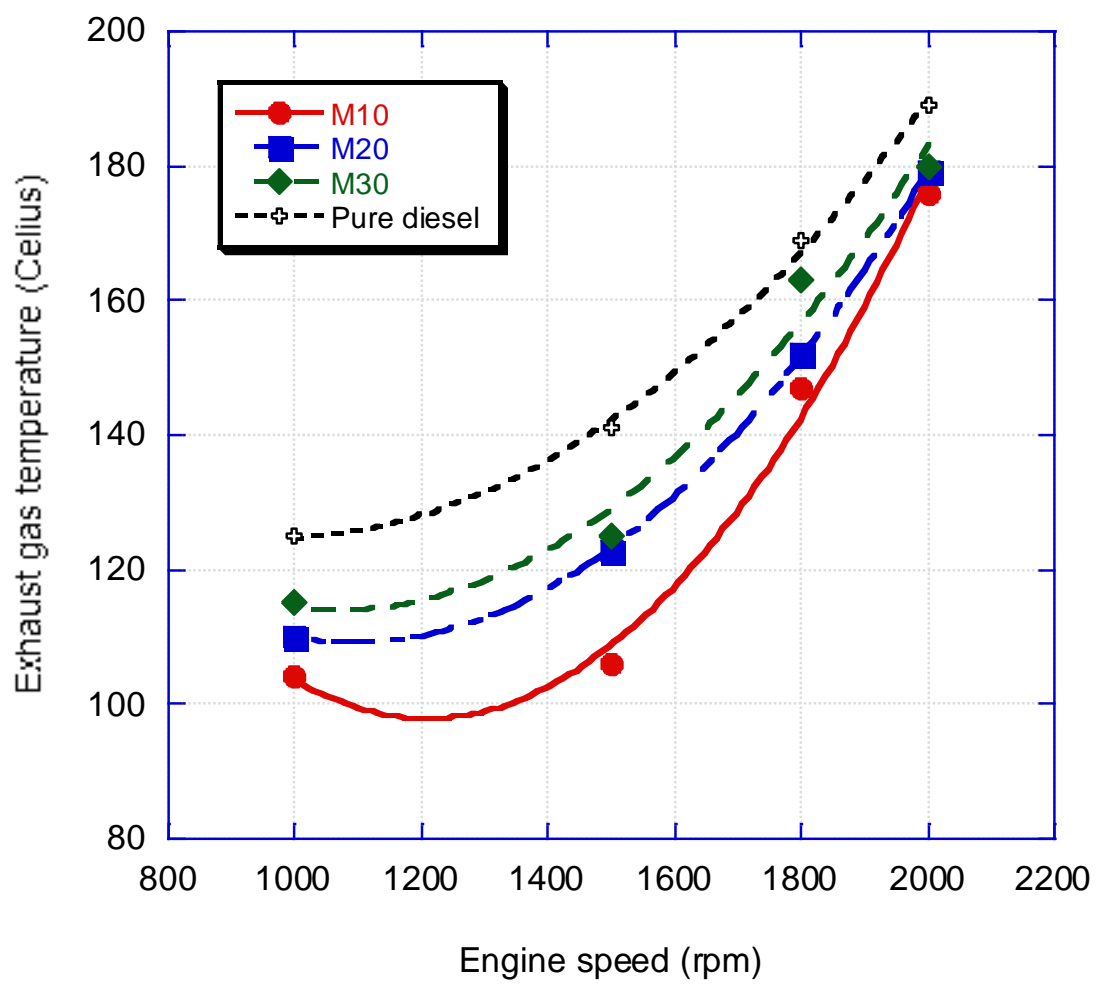

Figure 7. Exhaust gas temperature vs. engine speed for different methanoldiesel blended fuels at full load

\section{CONCLUSION}

Methanol-diesel blended fuel was successfully tested in a diesel engine. Experimental results showed that the output power and torque for the methanol-diesel blend fuel were higher than for the conventional diesel fuel alone. The exhaust gas temperature was found to be higher when the diesel fuel was used alone compared to the blended fuel. Also, the brake specific fuel consumption for the mixed fuel was lower than for the pure diesel fuel. It has been shown in this research that the addition of $10 \%$ methanol to the diesel fuel may have a great impact on the engine performance and the environment.

\section{ACKNOWLEDGMENTS}

The authors are obliged to the University of Southern Queensland for providing laboratory facilities and financial assistance.

\section{REFERENCES}

Adelman, H.G., Andrews, D. G., \& Devoto, R. S. (1972). Exhaust emission from a methanol-fuelled automobile. SAE Transactions, 81, 720693.

Azad, A. K., Ameer Uddin, S. M., \& Alam, M. M. (2012). A comprehensive study of DI diesel engine performance with vegetable oil: an alternative boi-fuel source of energy. International Journal of Automotive and Mechanical Engineering, 5, 576-586. 
Bayraktar, H. (2008). An experimental study on the performance parameters of an experimental CI engine fueled with diesel-methanol-dodecanol blends. Fuel, 87, 158-164

Ghobadian, B., Najafi, G., \& Nayebi, M. (2013). A semi-empirical model to predict diesel engine combustion parameters. Journal of Mechanical Engineering and Sciences, 4, 373-382.

Ghobadian, B., Najafi, G., Rahimi, H., \& Yusaf, T. (2009). Diesterol: an environmentfriendly IC engine fuel. Renewable Energy Journal, 34(1), 335-342.

Havemann, H. A., Rao, M. R. K., Nataryan, A., \& Narasimhan T. L. (1954). Alcohols in diesel engines. Automobile Engineer, 256-262.

Klaus. B., \& Pederson, P. S. (1977). Alternative diesel engine fuels: an experimental investigation of methanol, ethanol, methane and ammonia in a D. I. diesel engine with pilot injection. SAE Paper, 770794.

Liao, S. Y., Jiang, D. M., Cheng, Q., Huang, Z. H., \& Wei, Q. (2005). Investigation of the cold start combustion characteristics of ethanol-gasoline blends in a constant-volume chamber. Energy and Fuels, 19, 813-819.

Lin, T. C. \& Chao, M. R. (2002). Assessing the influence of methanol-containing additive on biological characteristics of diesel exhaust emissions using microtox and mutatox assays. The Science of the Total Environment, 284, 61-74.

Liu, S. H., Clemente, E. R., Hu, T. G., \& Wei, Y. (2007). Study of spark ignition engine fuelled with methanol/gasoline fuel blends. Applied Thermal Engineering, 27, 1904-1910.

Liu, S. H. \& Li, H. (2006). Effects of methanol-gasoline blend on SI engine performance and emissions. Journal of Xi'an Jiaotong University, 40(1), 1-4.

Lu, S. H. \& Liu, S. H. (2006). Measurement of non-regulated pollutants from SI engine fuelled with methanol/gasoline blends. Transactions of CSICE, 24(1), 57-61.

Mat Yasin, M. H., Mamat, R., Sharma, K. V., \& Yusop, A. F. (2012). Influence of palm methyl ester (PME) as an alternative fuel in the multicylinder diesel engine. Journal of Mechanical Engineering and Sciences, 3, 331-339.

Özaktas, T., Ergeneman, M., Karaosmanoglu, F., \& Arslan, H. A. (2000). Ignition delay and soot emission characteristics of methanol-diesel fuel blends. Petroleum Science and Technology, 18(1-2), 15-32.

Qi, D. H., Chen, H., Geng, L. M., Bian, Y. Z. H., \& Ren, X. C. H. (2010). Performance and combustion characteristics of biodiesel-diesel-methanol blend fuelled engine. Applied Energy, 87, 1679-1686.

Rahim, R. Mamat, R., Taib, M. Y., \& Abdullah, A. A. (2012). Influence of fuel temperature on a diesel engine performance operating with biodiesel blended. Journal of Mechanical Engineering and Sciences, 2, 226-236.

Sayin, C., Ilhan, M., Canakci, M., \& Gumus, M. (2009). Effect of injection timing on the exhaust emissions of a diesel engine using diesel-methanol blends. Renewable Energy, 34, 1261-1269.

Sayin, C., Ozsezen, A. N., \& Canakci, M. (2010). The influence of operating parameters on the performance and emissions of a DI diesel engine using methanol-blendeddiesel fuel. Fuel, 89, 1407-1414.

Sundar Raj, C., \& Sendilvelan, S. (2010). Effect of oxygenated hydrocarbon additives on exhaust emission of a diesel engine. International Journal of Automotive and Mechanical Engineering, 2, 144-156. 
Warring, P. (1993). Alternative vehicle fuels: combustion equipment for methanol in Otto and diesel engine. Industrial Processing Division, Wellington, New Zealand.

Warring, P. (1993). Fuel the future. National Seminar on Hydrogen and Methanol: University Kebangsaan Selangor, Malaysia.

Yao, C., Cheung, C. S., Cheng, C., Wang, Y., Chan, T. L., \& Lee, S. C. (2008). Effect of diesel/methanol compound combustion on diesel engine combustion and emissions. Energy Conversion and Management, 49, 1696-1704.

Yuksel, F. \& Yuksel, B. (2004). The use of ethanol-gasoline blend as a fuel in an SI engine. Renewable Energy, 29(7), 1181-1191.

Yusaf, T. (2009). Experimental investigation of a single cylinder diesel engine as a hybrid power unit for a series hybrid electric vehicle. Journal of Energy Resources Technology, 131, 12203-12207. 